\title{
Stabilizacija gležnja fibularnim periostealnim režnjem u liječenju kronične lateralne nestabilnosti gležnja
}

\section{Ankle joint stabilisation with fibular periosteal graft in treatment of chronic lateral ankle instability}

\author{
Hrvoje Klobučar
}

\begin{abstract}
Sažetak. Cilj: Cilj rada jest prikazati rezultate anatomske stabilizacije kronično nestabilnog gležnja uz augumentaciju fibularnim periostealnim režnjem. Ispitanici i metode: Ukupno 7 muškaraca i 7 žena s kroničnom nestabilnošću gležnja, medijan životne dobi 37 godina (20 61 godinu), liječeno je operacijski transponiranim fibularnim periostealnim režnjem. Transponirani periostealni režanj fiksiran je sidrima ili transosealnim šavima za kost talusa i petne kosti, u rekonstrukciji prednjeg talofibularnog i kalkaneofibularnog ligamenta. Svi pacijenti analizirani su AOFAS i FADI biljezima prije operacije i najmanje godinu dana nakon zahvata. Rezultati: Prijeoperacijski AOFAS porastao je s medijana $47(17-82)$ na medijan 95 (84 - 100) nakon stabilizacije periostealnim fibularnim režnjem $(p<0,05)$. Medijan preoperacijskog FADI-ja iznosio je 89,2 (13,8 - 95,2), a nakon operacije medijan FADI-ja iznosio je $95(79,5-98,8)(p<0,05)$. Četrnaest pacijenata vratilo se svojim redovitim životnim i sportskim aktivnostima. Anatomske metode stabilizacije gležnja daju bolje funkcijske rezultate $u$ odnosu na neanatomske metode. Periostealno tkivo s fibule čvrsto je i odlično se remodelira, te nakon godinu dana u cijelosti formira originalni ligament. Većina istraživanja različitih oblika korištenja fibularnog periostealnog režnja u lateralnoj stabilizaciji gležnja, bez obzira na način i vrstu fiksacije, daje odlične funkcijske rezultate. Zaključak: Metoda lateralne stabilizacije gležnja periostealnim presatkom s fibule pouzdana je metoda liječenja kronične lateralne nestabilnosti gležnja.
\end{abstract}

Ključne riječi: kronična lateralna nestabilnost gležnja; periostealni fibularni režanj; stabilizacija gležnja

\begin{abstract}
Aim: The aim of this article is to evaluate the method of anatomical stabilization of a chronically unstable ankle with augmentation with a fibular periosteal graft. Patients and Methods: A total of 7 men and 7 women with chronic ankle instability, with an median age of 37 years (20-61 years), were treated by surgically transposed fibular periosteal graft. The transposed periosteal flap is fixed by anchors or transoseal sutures on the talus and calcaneus, in reconstruction of the anterior talofibular and calcaneofibular ligaments. All patients were analyzed with AOFAS and FADI scores before surgery and at least one year after surgery. Results: Preoperative AOFAS increased from median 47 (17-82) to median 95 (84-100) after stabilization with periosteal fibular lobe $(p<0.05)$. The median preoperative FADI was 89.2 (13.8-95.2), and after surgery, the median FADI was $95(79.5-98.8)(p<0.05)$. Fourteen patients returned to their regular life and sports activities. Anatomical ankle stabilization methods give better functional results than non-anatomical methods. The periosteal tissue from the fibula is firm and remodels perfectly, forming a whole ligament after a year. Most studies of different techniques of using fibular periosteal graft, in lateral ankle stabilisation regardless of the type of fixation, give excellent functional results. Conclusion: The lateral ankle stabilization method with periosteal fibular graft is a reliable method of treating chronic lateral ankle instability.
\end{abstract}

Key words: ankle stabilization; chronic lateral ankle instability; periosteal fibular graft
„Akromion“, specijalna bolnica za ortopediju, Krapinske Toplice

Dopisni autor:

Dr. sc. Hrvoje Klobučar, dr. med., „Akromion“, specijalna bolnica za ortopediju Ljudevita Gaja 2, 49217 Krapinske Toplice E-mail: hrvoje.klobucar@akromion.hr

http://hrcak.srce.hr/medicina 


\section{UVOD}

Inverzijske ozljede gležnja čine ukupno $25 \%$ svih ozljeda koštano-zglobnog sustava ${ }^{1}$. Ozljede lateralnog ligamentarnog kompleksa čine ukupno oko 85 \% svih ozljeda ligamenata gležnja². Lateralni ligamentarni kompleks čine prednji talofibularni ligament (ATFL), kalkaneofibularni ligament (CFL) i stražnji talofibularni ligament (PTFL) (slika 1a). Prednji talofibularni ligament polazi s anteroinferiornog ruba fibule i završava na proksimal-

Brojne su metode stabilizacije kronično nestabilnog gležnja, a sve uglavnom daju relativno dobre dugoročne rezultate. Metoda stabilizacije gležnja lateralnim periostealnim fibularnim režnjem jednostavna je i tehnički lako izvediva metoda koja daje dobru čvrstoću rekonstruiranog kompleksa. Periost se s vremenom remodelira tvoreći ligamentarnu strukturu.

nom dijelu vrata talusa, neposredno ispred artikularne plohe talusa. Nalazi se neposredno uz zglobnu čahuru, a može se sastojati od jednog ili dva tračka ${ }^{3,4}$. Stražnji talofibularni ligament polazi sa stražnjeg ruba lateralnog maleola fibule i završava na lateralnom tuberkulu talusa, a kalkaneofibularni ligament proteže se od donjeg ruba fibularnog maleola, prolazi ispod peronealnih tetiva i ide do lateralnog tuberkula kalkaneusa, ${ }^{5,6}$. Uganuće gležnja najčešće se događa forsiranom inverzijom plantarno flektiranog stopala s položajem pete u unutarnjoj rotaciji (supinacijska ozljeda), dok se proksimalni dio noge nalazi u vanjskoj rotaciji. Pri tom ATFL, kao najslabija karika lateralnog ligamentarnog kompleksa, najčešće puca,
CFL nešto rjeđe, a PTFL biva ozlijeđen u manje od $10 \%$ ovakvih uganuća ${ }^{6,7}$. Važno je naglasiti da jedino CFL od svih ligamenata lateralnog ligamentarnog kompleksa ima značajnu ulogu u stabilizaciji subtalarnog zgloba, koji također može biti zahvaćen uganućem. Subtalarna nestabilnost često je suptilna i nije ju lako evaluirati kliničkim pregledom $^{8}$. Akutne rupture ligamenata uglavnom se liječe neoperacijski. Operacijsko liječenje akutnih ruptura ligamenata može biti indicirano kod aktivnih sportaša. Opetovane supinacijske ozljede lateralnog ligamentarnog kompleksa mogu dovesti do kronične insuficijencije ovog ligamentarnog sustava radi cijeljenja ligamenata slabije čvrstim ožiljnim tkivom koje ne izdržava stres poput intaktnog ligamenta (slika 1b). Također, ozljeda ligamenata dovodi do oštećenja propriocepcijskog sustava, što oslabljuje pozicijski osjet stopala i gležnja, predisponirajući već ozlijeđen gležanj novim ozljedama ${ }^{9,10}$.

Kroničnom nestabilnosti možemo definirati epizode ponavljanih uganuća ili osjećaja nestabilnosti gležnja koje traju barem godinu dana nakon inicijalnog uganuća gležnja ${ }^{11}$. Kroničnu lateralnu nestabilnost gležnja (engl. chronic lateral ankle instability, CLAI) možemo prema razlozima nastanka razlučiti kao mehanički CLAl (ligamentarni laksitet, anatomske promjene ligamenata koje dovode do značajnih poremećaja u artrokinematici) i funkcionalni CLAl (oštećenje propriocepcije i poremećaj neuromuskularne koordinacije), iako nerijetko koegzistiraju oba ova elementa nestabilnosti ${ }^{12-14}$. Varus pete, pojačana fleksija prve metatarzalne kosti, kavus stopala ili opće povećana gibljivost zglobova mogu predisponirati gležanj razvoju CLAl. Ovisno o inicijalnom liječenju akutnog uganuća, kronične nestabilnosti gležnja

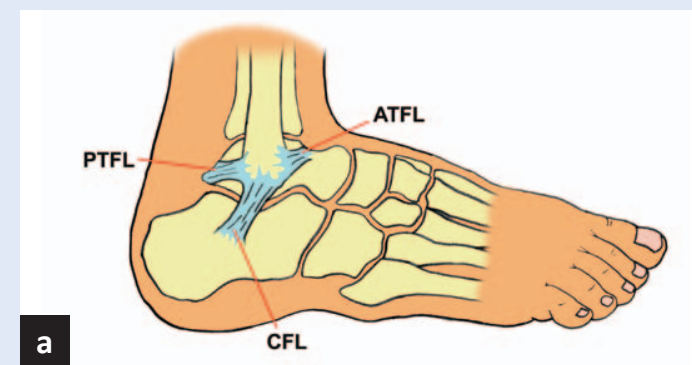

b

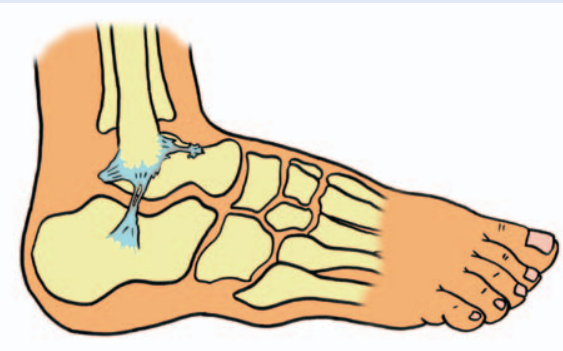

Slika 1. Lateralni ligamentarni kompleks gležnja; a) intaktni ligamentarni sustav; ATFL -prednji talofibularni ligament, CFL - kalkaneofibularni ligament, PTFL - stražnji talofibularni ligament, b) kronična lezija APFL-a i CFL-a, uz prikazan pomak (nestabilnost) gornjeg i donjeg nožnog zgloba. 
javljaju se u populaciji od $4-5 \%$ svih akutnih uganuća gležnja do 10 - $30 \%$, a operacijsko liječenje savjetuje se tek nakon šestomjesečnog pokušaja neoperacijskog liječenja ${ }^{15}$.

\section{KLINIČKI NALAZ}

Kronična lateralna nestabilnost gležnja očituje se epizodama opetovanih uganuća gležnja, nesigurnosti prilikom stajanja i hoda po neravnim terenima. Vrlo važno je analizirati svodove stopala, položaj pete i usmjerenje donjeg ekstremiteta, te procijeniti stupanj varusa pete ili kavusa stopala koji mogu povećati opterećenje na lateralni dio stopala. Prilikom kliničkog pregleda treba evaluirati neurološki status ekstremiteta, napraviti testiranje općeg laksiteta zglobova, pogledati opseg pokreta u gležnju i funkciju peronealne muskulature. Testom prednje ladice evaluira se status ATFL-a. Ovaj test izvodi se u neutralnom položaju stopala i povlačenjem talusa i stopala prema naprijed. Uvijek je potrebno napraviti usporedbu sa suprotnom stranom. Talar tilt test izvodi se zadržavajući gležanj u dorzalnoj fleksiji i forsiranjem pozicioniranja pete $i$ talusa u inverzijski položaj. Ovim testom evaluira se $\mathrm{CFL}^{7,11,14,16,17}$.

\section{DIJAGNOSTIČKA OBRADA}

Radiološke stres snimke još uvijek se smatraju zlatnim standardom u dijagnostici nestabilnosti. Smatra se da prednji pomak talusa u odnosu na tibiju za $>10 \mathrm{~mm}$ kod stres testa prednje ladice ili $>9^{\circ}$ nagnuća talusa u odnosu na tibiju prilikom izvođenja stres testa talar tilta možemo smatrati značajnim u evaluaciji ozljede ATFL-a ili CFL-a ${ }^{1,18}$. Ozljedu ligamenata gležnja dobro možemo prikazati ultrazvučnim pregledom i pregledom magnetskom rezonancijom ${ }^{19,20}$. Međutim, za potvrdu dijagnoze CLAI magnetska rezonancija neće biti dovoljna, s obzirom na to da će ozlijeđeni ligament redovito biti prikazan kao fibrozno zadebljana struktura, s ili bez koštanih fragmenata. Potrebno je napraviti dinamičku evaluaciju funkcionalnog statusa ligamenta. U odnosu na radiološke stres snimke, manje štetna metoda za pacijenta je dinamični ultrazvučni pregled ligamenata gležnja koji ortoped može napraviti u ambulanti, tj. kao nadopunu kliničkom pregledu (slika 2). Dinamičkim pregledom
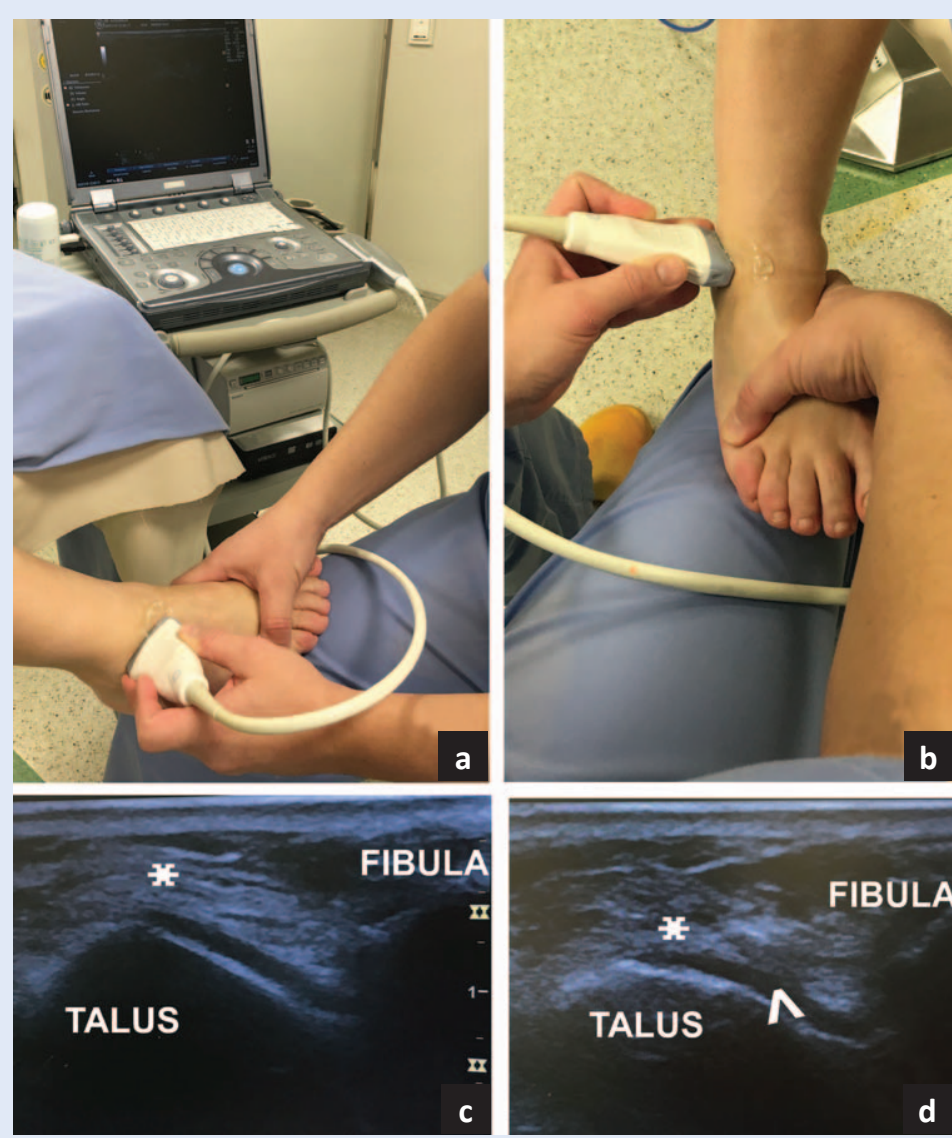

Slika 2. Dinamički ultrazvučni pregled prednjeg talofibularnog ligamenta. a) Stopalo slobodno visi preko ruba stola, oslonjeno na koljeno ultrasoničara, u položaju blage plantarne fleksije. Ultrazvučna sonda postavljena je duž prednjeg talofibularnog ligamenta. b) Ultrasoničar povlači stopalo $u$ položaj prednje ladice, zadržavajući sondu iznad prednjeg talofibularnog ligamenta. c) Ultrazvučni prikaz prednjeg talofibularnog ligamenta $(*)$ u neutralnom položaju. d) Ultrazvučni prikaz insuficijencije prednjeg talofibularnog ligamenta $(*)$ u položaju prednje ladice - mjesto lezije ligamenta označeno je strjelicom (>).

može se evaluirati prednji talofibularni ligament prilikom izvođenja testa ladice te kalkaneofibularni i deltoidni ligament prilikom izvođenja talar tilt testa. Ultrazvučnim pregledom i magnetskom rezonancijom također se mogu analizirati eventualne prateće ozljede okolnih tetiva, a magnetska rezonancija evaluira i eventualne hrskavične ozljede gležnja $a^{7,19,21-23}$.

\section{LIJEČENJE}

Kroničnu lateralnu nestabilnost gležnja uvijek treba započeti liječiti neoperacijski. To liječenje temelji se na funkcionalnom i preventivnom programu. Prevencija uganuća korištenjem različitih ortoza ili bandaža mora biti nadopunjena vježbama stimulacije propriocepcije i neuromu- 
skularne aktivacije. Rehabilitacijski program trebao bi trajati najmanje $2-3$ mjeseca $^{1,16}$.

Operacijsko liječenje temelji se na rekonstrukciji ligamenata. Na raspolaganju su artroskopske metode te otvorene metode stabilizacije ${ }^{23}$. U dugoročnom pogledu rezultati su jednako dobri ako se zahvati tehnički korektno izvedu uz odgovarajuće iskustvo operatera u izvođenju određenih metoda rekonstrucije, a bez obzira na odabranu metodu (otvorenu ili artroskopsku) ${ }^{24}$. Općenito, metode stabilizacije lateralnog ligamentarnog sustava gležnja dijele se na neanatomske i anatomske metode. Najčešće korištene metode stabilizacije su; rafija tkiva prednjeg talofibularnog ligamenta (Bröstrom) stabilizacija ekstenzornim retinakulom (Bröstrom-Gould) transpozicija tetive peroneus brevisa (Watson-Jones, Evans, Crisman-Snock), korištenje presatka tetiva semitendinozusa, gracilisa ili patelarnog ligamenta, te korištenje režnja peri-

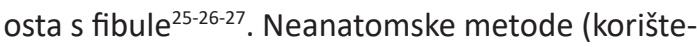
nje tetive peroneus brevisa najčešća je metoda tenodeze) mogu utjecati na opseg pokreta u gležnju, mogu povećati lateralno plantarno opterećenje $u$ hodu i mijenjati sam hod pacijenta promjenom propriocepcije ${ }^{28-29}$. Zato je danas uglavnom naglasak na anatomskim metodama stabilizacije gležnja. Jedna od ovih metoda je i metoda rekonstrukcije lateralnog ligamentarnog kompleksa uz korištenje režnja fibularnog periosta koju su opisali Glas i sur. $1985 .{ }^{30}$

Za razliku od ostalih metoda augumentacije (tetive semitendinozusa ili gracilisa), korištenjem fibularnog periosta nije potrebno koristiti druga tkiva s udaljenih lokacija, te nije potrebno koristiti tetivu peroneus brevisa. Rezultate predložene metode obradili su istraživači u različitim studija$\mathrm{ma}^{31,32}$. Svakako valja napomenuti da se primjena tehnike priostealnog fibularnog režnja razlikuje $s$ obzirom na način fiksacije režnjeva. Ozaki i suradnici prikazali su rezultate augumentacije lateralnog ligamentarnog kompleksa periostealnim režnjem s fibule koji autori šivaju uz ATFL i CFL. Ovom tehnikom autori su u postupku praćenja pacijenata uočili AOFAS od 97,232. Funkcionalni rezultat anatomske stabilizacije gležnja periostealnim režnjem prema studiji Rosenbauma i suradnika jednak je neanatomskoj metodi peronealne tenodeze po Evansu godinu dana nakon zahva$\mathrm{ta}^{33}$.

\section{PACIJENTI I METODE}

\section{Pacijenti}

$U$ istraživanju je sudjelovalo 14 ispitanika liječenih operacijski transponiranim fibularnim periostealnim režnjem radi kronične nestabilnosti gležnja. U analizu je uključeno 7 muškaraca i 7 žena, medijan životne dobi bio je 37 godina (20 61 godina), u deset slučajeva radilo se o stabilizaciji desnog, a u četiri slučaja lijevog gležnja. Jedan pacijent bio je aktivni sportaš, a trojica redoviti rekreativni sportaši.

\section{Klinički pregled}

Sve pacijente pregledao je isti ortoped. U kliničkoj evaluaciji pozornost je usmjerena na hod pacijenta; pravocrtno i nepravilno („cik-cak“) kretanje te oblik i položaj stopala. Evaluirani su svodovi stopala i položaj pete. Ako je uz lateralnu nestabilnost gležnja bila prisutna varus deformacija stražnjeg dijela stopala, u istom aktu sa zahvatom stabilizacije gležnja napravljena je korektivna lateralizacijska osteotomija petne kako bi se restaurirala osovina gležnja. Napravljena je analiza opsega pokreta u gornjem i donjem nožnom zglobu, te funkcija okolnih tetiva (osobito peronealne muskulature). Evaluirala se stabilnosti gležnja testom ladice te talar tilt testom, te eventualna prisutnost testova opće povećanog laksiteta zglobova. Napravljen je i dinamički pregled gležnja; Y balance test, single leg stance test, side hop test.

Kod svih pacijenata prije zahvata stabilizacije evaluirani su AOFAS (American Orthopaedic Foot and Ankle Society Score) i FADI (Foot and Ankle Disability Indeks) prije zahvata. FADI anketira pacijenta s obzirom na aktivnosti koje može izvoditi u pet razina (bez tegoba, blage tegobe, umjerene tegobe, izrazite tegobe, neizvedivo). Svaki odgovor se boduje. Upitnik odgovara na ukupno 26 različitih pitanja vezanih uz svakodnevne aktivnosti (hod po različitim terenima, stajanje, čučanje, penjanje, odizanje na prste, rekreacijske aktivnosti, bol itd.). Maksimalni zbroj bodova je 100, te se razina aktivnosti ocjenjuje ukupnim postotkom mogućnosti obavljanja normalnih životnih aktivnosti. FADI ne određuje potkategorije kao neki drugi sustavi bodovanja. AOFAS se sastoji od uku- 
pno devet pitanja (kategorija); bol, funkcijska ograničenja aktivnosti, hodna pruga (distanca hoda), hod po različitim površinama, poremećaji hoda, kretnje gležnja u sagitalnoj ravnini, pokretljivost stražnjeg dijela stopala, poravnanje stopala, pete i potkoljenice te stabilnost gležnja u sagitalnoj i frontalnoj ravnini. Svaka od ovih kategorija različito se boduje, bodovi se zbrajaju te se može ostvariti maksimalni zbroj od 100 bodova. Rezultat između 90 i 100 bodova smatra se izvrsnim, dobrim rezultatom smatra se AOFAS u vrijednosti od 80 do 89 , umjereno dobrim smatra se rezultat u vrijednosti $60-79$, a svaki AOFAS ispod razine 60 bodova smatra se lošim rezultatom ${ }^{34}$.

\section{Dijagnostička obrada}

Kod svih pacijenata napravljen je ultrazvučni dijagnostički pregled; statički i dinamički. Napravljena je standardna radiološka dijagnostika radi isključenja koštanih lezija, a ako je postojala klinička indikacija kod otklona osovine pete i gležnja, uz standardne radiograme napravljena je i „hindfoot alignement view“ projekcija, radi planiranja korektivne osteotomije petne kosti.

\section{Kirurška tehnika stabilizacije gležnja periostealnim režnjem}

Operacijski zahvat izvodi se u spinalnoj anesteziji, u blijedoj stazi distalnog dijela potkoljenice. U tu svrhu Esmarchova poveska postavlja se na središnji dio potkoljenice ili na natkoljenicu. Ako je prethodno potrebno napraviti artroskopiju gležnja, onda se pacijent namješta u položaj na leđima, iako je artroskopski zahvat na gležnju moguće napraviti i u bočnom položaju pacijenta. Artroskopski zahvat napravi se na standardan način, te se artroskopski portali zatvore. Napravi se lučni rez počevši $5-7 \mathrm{~cm}$ iznad vrška fibule, rez zavije preko vrška fibule i završava na vratu talusa. Prikaže se prednji talofibularni ligament, te kalkaneofibularni ligament otvorivši ovojnicu peronealnih tetiva. Evaluira se status ovih ligamenata i izmjeri duljina potrebna za augumentaciju. Prikaže se distalna tibija te odredi i izmjeri područje potrebno za odizanje periostealnog režnja (slika 3a). Ovisno o potrebnoj duljini i opsegu rekonstrukcije (samo prednji talofibularni, samo kalkaneofibularni ligament ili oba) odvoji se jedan ili dva izdužna fibularna periostealna režnja u

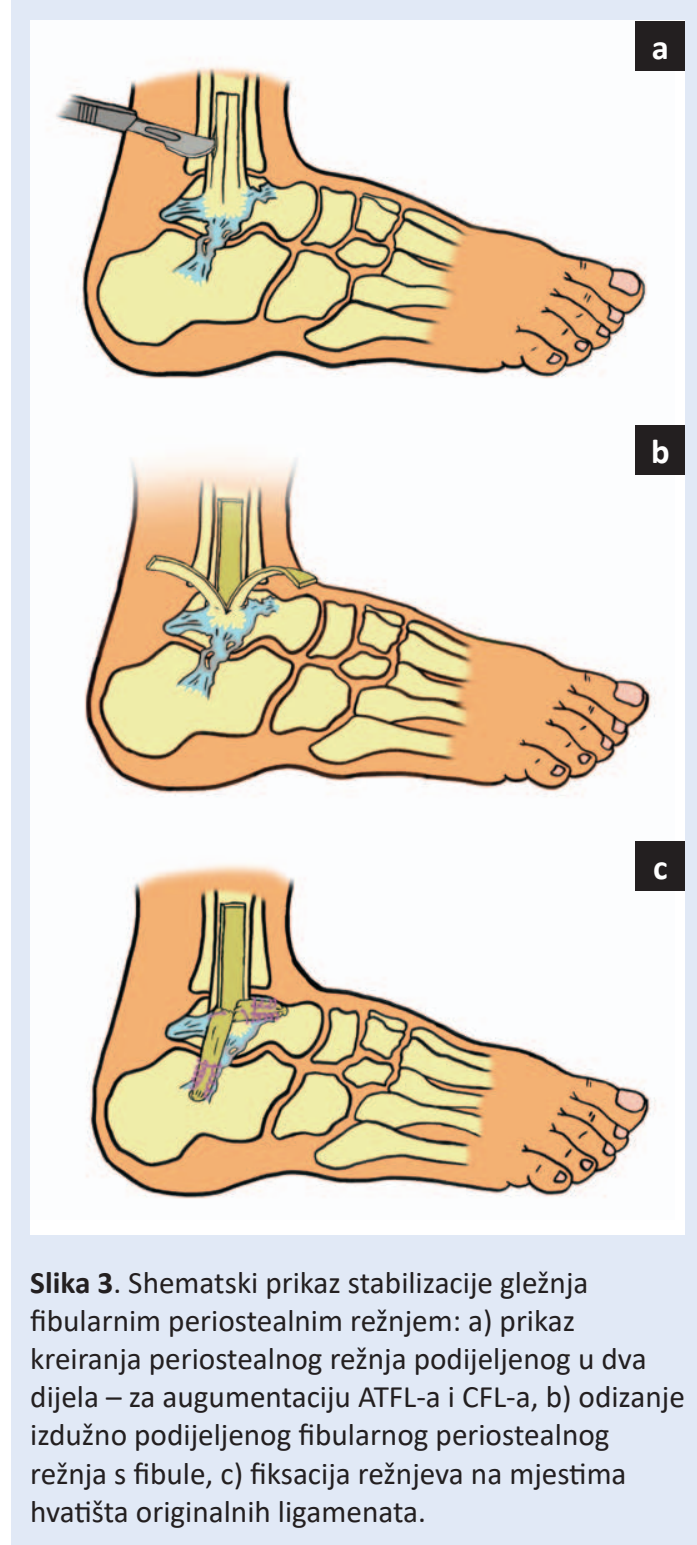

smjeru od proksimalno prema distalno, te odignu od koštane strukture fibularnog maleola (slika 3b, slika 4a-c). Distalno se s dva transosealno položena Ethibond konca USB\#2 fiksiraju oba režnja uz periost. Prikaže se mjesto hvatišta („footprint“) prednjeg talofibularnog ligamenta na talusu i kalkaneofibularnog ligamenta na petnoj kosti (u smjeru stražnjeg ruba fibularnog maleola). Napravi se toaleta „footprinta“ na talusu i na kalkaneusu dlijetom. Periostealni režnjevi fiksiraju se uz kost (slika 3c, slika 4d).

Tehnike fiksacije periostealnog režnja razlikuju se ovisno o vrsti materijala i načinu fiksacije.

1. Kad se fiksacija izvodi metalnim sidrom (Mitek G2), tada se najprije kroz sidro provuku dva Orthocord konca ili dva Fiberwire konca 

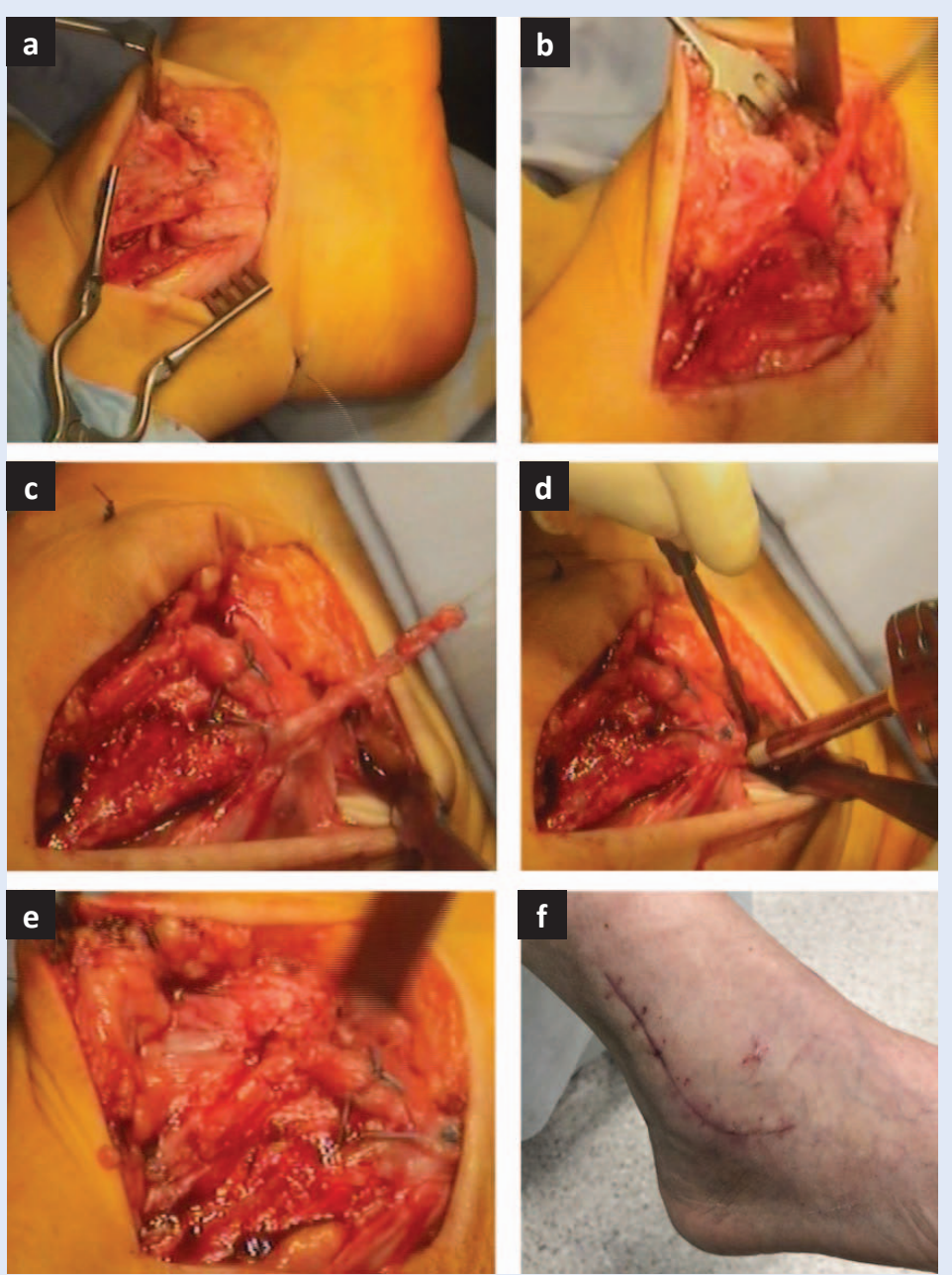

Slika 4. Tehnika rekonstrukcije prednjeg talofibularnog i kalkaneofibulanrog ligamenta fibularnim periostealnim režnjem. a) Odignuta su dva tračka periosta s fibule, b) prednji tračak periostealnog režnja odignut je i pripravan za rekonstrukciju, c) prednji tračak periostealnog režnja fiksiran je na talusu na mjestu prednjeg talofibularnog ligamenta, a odignut je stražnji tračak, d) stražnji tračak periostealnog režnja provlači se ispod peronealnih tetiva i fiksira u petnoj kosti s Biotenodesis Screw (Arhtrex) - na mjestu kalkaneofibularnog ligamenta, e) prikaz po rekonstrukciji lateralnog ligamentarnog kompleksa s dva režnja periosta fibule, f) izgled gležnja dva mjeseca nakon zahvata.
USB \#2/0. Probuši se ležište za sidro svrdlom 2,7 mm u središnjem dijelu „footprinta“ odgovarajućeg ligamenta i postavi titansko sidro. Režnjevi se rotiraju i prošiju Krakow šavom Orthocord ili Fiberwire koncem samo jednim krakom jednog konca sa svake strane periostealnog režnja. Odredi se tenzija režnja zadržavanjem stopala u neutralnom položaju fleksije i blagoj everziji stopala od $5^{\circ}$. Preostali krak svakog konca provuče se kroz periostealni režanj na mjestu kontakta režnja s kosti. Šivaju se svi konci uz zadržavanje stopala $u$ neutralnom položaju fleksije i u blagoj everziji stopala od $5^{\circ}$. Ako je režanj dovoljno dugačak, može se preklopiti i šivati ponovno za fibulu u područje prethodno postavljenih transosealnih šavi koji osiguravaju bazu ligamentarnog kompeksa.

2. Kad se fiksacija izvodi s resorptivnim sidrom (Gryphone ${ }^{\circledR}$, DePuy) tehnika je slična kao pod 1 , a uz sidro je isključivo vezan Orthocord konac.

3. Ako se fiksacija izvodi s Biotenodesis Screw (Arthrex) - koristi se sidro od 4,5 mm/15 mm (slika 4). U tom slučaju prvo se izmjeri duljina svakog režnja koji ulazi u koštani kanal tako da se stopalo zadržava u neutralnom položaju fleksije i everziji od $5^{\circ}$, a režanj je pod tenzijom. Odredi se duljina od $15 \mathrm{~mm}$ svakog od dva režnja koji ulaze u kost, potom se periostealni režanj prošije jednim Krakow šavom Fiberwire koncem USB \#2/0 s obje strane periostealnog režnja, tako da su oba slobodna kraka konaca izvučena prema vrhu svakog režnja. Probuši se otvor u središnjem dijelu „footprinta“ na talusu i kalkaneusu svrdlom 5 $\mathrm{mm}$, u dubinu od $15 \mathrm{~mm}$. Jedan konac provlači se kroz vrh sidra, a drugi je slobodan. Postavlja se sidro u kost uz zatezanje konaca, zadržavanjem stopala u neutralnoj fleksiji i everziji od $5^{\circ}$. Tako fiksiran režanj dovoljno je stabilan, međutim, može se dodatno pritisnuti čvor između oba kraka Fiberwire konca iznad postavljenog sidra (slika 4).

4. Kod transosealne fiksacije periostealnog režnja šavima, kroz prethodno formirane tunele na kosti iglom se provlači šav koji Krakow tehnikom prošiva periostealni režanj.

Bez obzira kako je fiksacija napravljena, rekonstruirani kompleks dodatno se osigurava šivanjem proksimalnog ruba ekstenzornog retinakula za fibularni maleol ili na mjestu prethodno postavljenih transosealnih šavi ili kroz dodatno postavljena dva transosealna tunela. Prilikom postavljanja transosealnih tunela kod mlađih osoba i čvršće kosti potrebno je napraviti otvore svrdlom 2,0 mm ili Kirschnerovom žicom 1,8 mm u fibuli, a kod manje čvrste kosti moguće je provući Ethibond konac USB\#2 iglom kroz kost, bez bušenja kosti, te njime dodatno učvrstiti ekstenzorni retinakul uz fibulu. Rana se zatvara po sloje- 
vima. Na ranu se postavi Molndal povoj (Aquacel + Granuflex), potom vatirani povoj i elastični zavoj, a noga se stavlja u longetu u blagoj everziji stopala od $5^{\circ}$. Nakon 5 dana uklanja se longeta i Molndal povoj, a noga se nadalje zadržava u walker ortozi kroz idućih 9 dana. $U$ tom periodu pacijenta se instruira da zadržava operirani gležanj u povišenom položaju i dozvoljeno je opterećivanje operiranog stopala dodirom podloge (do cca $10 \mathrm{~kg}$ opterećenja operirane noge). Dva tjedna nakon zahvata uklanjaju se šavi, te se postavlja fiberglas potkoljena čizma, ako je splasnula oteklina, ili se nastavlja koristiti walker ortoza, ako je to dovoljno komforno za pacijenta. Fiberglas potkoljena čizma kao i walker ortoza postavlja se u neutralnom položaju, uzdužno se otvori fiberglas. Nadalje, pacijentu je dozvoljeno dva-tri puta na dan izvaditi nogu iz imobilizacije i izvoditi vježbe fleksije i ekstenzije stopala, bez rotacija i bez everzije i inverzije stopala. Kroz idući period pacijent nastavlja hod s povećanim opterećivanjem operiranog stopala $+15-20$ kg tjedno do punog opterećenja (do pune tjelesne težine). U ovom periodu uključuju se izometričke vježbe jačanja mišića potkoljenice i elektrostimulacija mišića potkoljenice. Kad pacijent postigne opterećenje punom tjelesnom težinom (cca 6 tjedana po operaciji) dozvoljeno je započeti s punom mobilizacijom gležnja, dozvoljene su everzija i inverzija te rotacije stopala. Postupno se uključuju vježbe jačanja, dozvoljava se vožnja bicikla, započinje se s propriocepcijom. Povratak trčanju moguć je nakon 3 mjeseca, a povratak punim sportskim aktivnostima nakon 5 - 6 mjeseci.Kod 13 pacijenata periostealnim fibularnim režnjem rekonstruirani su prednji talofibularni i kalkaneofibularni ligamenti, a kod jedne pacijentice napravljena je transosealna fiksacija periostealnog režnja samo prednjeg talofibularnog ligamenta. Njoj je istovremeno napravljena i subtalarna artrodeza radi opsežnijih poslijetraumatskih hrskavičnih lezija subtalarnog zgloba. Kod 7 pacijenata napravljena je fiksacija s G2 sidrima (Mitek) na kojima je učvršćen Orthocord ili Fiberwire konac ili u kombinaciji ovih dvaju konaca. Dvoje pacijenata operirani su korištenjem Gryphone resorptivnih sidara (Depuy) s Orthocord koncima, a u četiri pacijenta učvršćenje periostealnog režnja za kost talusa i kalkaneusa napravljeno je korištenjem Biotenodesis Screw (Arthrex) uz Fiberwire konce.

\section{Praćenje}

Svih četrnaest pacijenata evaluirano je FADI-jem (Foot and Ankle Dissability Indeks-om) i AOFASom (American Orthopaedic Foot and Ankle Society Score) prije zahvata i najmanje godinu dana nakon zahvata ${ }^{35}$.

\section{Statistika}

Statistička obrada napravljena je u MS Windows 10 Excel programu, uz korištenje Analyse-it programa. Napravljena je analiza distribucije uzoraka Kolmogorov-Smirnovljevim Goodnes of Fit testom. Ispitivanje razlika vrijednosti varijabli AOFAS-a prije i nakon operacijskog zahvata te FADI-ja prije i nakon operacijskog zahvata napravljeno je neparametrijskim testiranjem Wilcoxonovim testom. Zaključivanje je napravljeno na razini značajnosti od $5 \%$.

\section{REZULTATI}

Medijan kliničkog praćenja bio je 50 mjeseci (7 92 mjeseca). Prijeoperacijski medijan AOFAS-a iznosio je 47 (17-82), a nakon stabilizacije periostealnim fibularnim režnjem medijan AOFAS-a bio je $95(84-100)(p<0,05)$. Prema kategorijama AOFAS-a, od četrnaest pacijenata jedan pacijent bio je umjereno dobar, dvoje pacijenata bilo je dobro, a jedanaest pacijenata bilo je izvrsno. Preoperacijski medijan FADI-ja iznosio je 89,2 $(13,8-95,2)$, a nakon operacije medijan FADI-ja bio je $95(79,5-98,8)(p<0,05)$ (slika 5$)$. Kod jed-

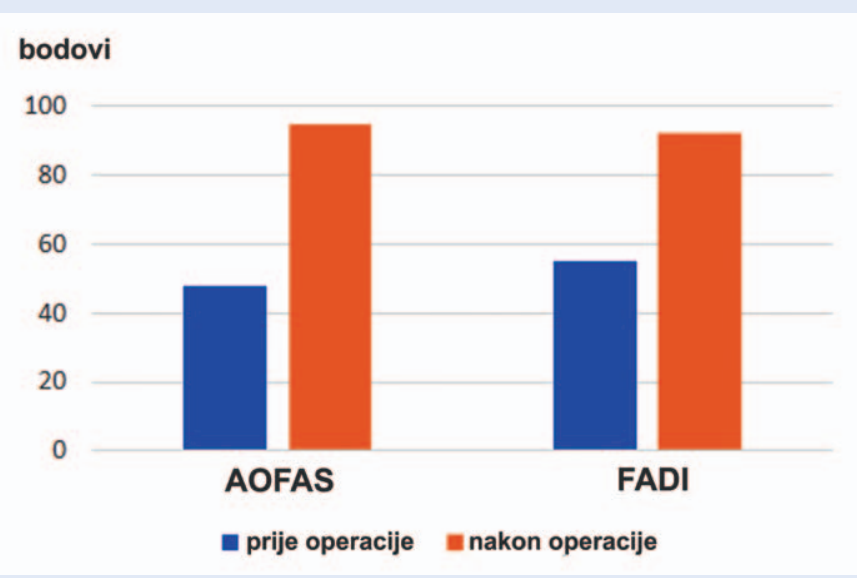

Slika 5. Grafički prikaz rezultata kliničkog praćenja pacijenata nakon stabilizacije gležnja periostealnim fibularnim režnjem. (AOFAS - American Orthopaedic Foot and Ankle Society Score, FADI - Foot and Ankle Disability Indeks). 
ne pacijentice bila je prisutna prolazna hipestezija u anterolateralnom dijelu stopala koja je $u$ potpunosti nestala četiri mjeseca nakon zahvata. Nije bilo infekcija, problema sa cijeljenjem rana, kontrakture gležnja niti rezidualne nestabilnosti gornjeg ili donjeg nožnog zgloba kod preostalih pacijenata.

\section{RASPRAVA}

Operacijsko liječenje CLAl neanatomskim metodama (Evans, Chrisman-Snook, Watson-Jones) uglavnom daju vrlo dobre rezultate u 80 - $85 \%$ pacijenata. Ne može se, međutim, ne istaknuti nedostatke ovih metoda, kao što su morbiditet donorskog mjesta, slabija everzija stopala, poremećaj kinematike subtalarnog zgloba ili reducirane kretnje gornjeg nožnog zgloba ${ }^{36}$. Zato se ove metode najčešće koriste kao revizijske metode. Opsežna metaanaliza Vuuberga i suradnika daje preporuke za odabir neke od anatomskih metoda rekonstrukcije u liječenju CLAI, a neanatomske metode mogu se koristiti u iznimnim slučajevima $i$ to uglavnom kao revizijske metode ${ }^{37}$. Benazzo i suradnici pokazali su da je metoda stabilizacije gležnja lateralnim periostalnim režnjem jednako učinkovita kao i ostale anatomske metode stabilizacije, te je učinkovita i kod akutnih uganuća gležnja ${ }^{38}$. U posljednje vrijeme značajnu popularnost dobivaju artroskopski asistirani zahvati stabilizacije gležnja, no oni zahtijevaju značajnu vještinu i izvježbanost operatera i odgovarajući instrumentarij i opremu. Usporedbe otvorene i artroskopske rekonstrukcije ATFL-a kod CLAl pokazuju da su obje metode podjednako uspješne promatrajući rezultate godinu dana nakon zahvata ${ }^{39,40}$.

Opisane su različite varijacije augumentacije lateralnog ligamentarog kompleksa periostealnim fibularnim režnjem ${ }^{9,32,41}$. Kombinacija modificirane Bröstrom metode uz augumentaciju periostealnim režnjem u studiji Karlssona i suradnika također je pokazala dobre rezultate ${ }^{9}$. Neke od tehnika augumentiraju standardnu Bröstrom-Gould tehniku rekonstrukcije bez fiksacije fibularnog režnja za talus ${ }^{36,41,42}$. Prednosti metode stabilizacije gležnja periostealnim režnjem $s$ distalne fibule su mnogostruke. Tehnički, radi se o jednostavnoj metodi, tkivo periosta dovoljno je čvrsto za restauraciju i augumentaciju oštećenog ligamenta, ne oštećuju se okolne tetive, čime se zadržava snaga everzije, nije potrebno korištenje udaljenih presadaka i razvoj morbiditeta donorskih mjesta, zadržava se anatomska rekonstrukcija koja omogućuje normalnu ili vrlo približno normalnu kinematiku gornjeg i donjeg nožnog zgloba. Mnoge studije ukazuju na odlične rezultate. Chew i suradnici objavljuju da su rezultati AOFAS-a značajno poboljšani sa 67 prije operacije na 89 nakon zahvata ${ }^{36}$. Choi i suradnici prikazali su jednako dobre rezultate $u$ pogledu AOFAS-a kod augumentacije periostealnim režnjem koji je povećan sa 60 prije operacije na 95 nakon operacije, u usporedbi s AOFAS-om kod primarne rekonstrukcije koji je povećan s 55 prije zahvata na 93 nakon operacije ${ }^{43,44}$. Bohnsack i suradnici u biomehaničkom istraživanju usporedili su različite vrste autolognih presadaka i zaključili da je periostealni presadak slabiji od tetivnih presadaka, ali ipak jednako dobar kao i originalni prednji talofibularni ligament. Dokazali su da je čvrstoća i otpornost na kidanje periostealnog režnja bolja od intaktnog prednjeg talofibularnog ligamenta. Također, periostealni režanj služi kao svojevrsni nosač za urastanje fibroblasta is vremenom se remodelira u pravu ligamentarnu struktu$\mathrm{ru}^{45}$. Ozaki i suradnici pokazali su da se periostealni režanj uzet s fibule odlično kolageno remodelira i pretvara u ligamentarno tkivo u periodu kraćem od dvanaest mjeseci nakon rekonstrukcije. Također ukazuju da je metoda korištenjem periostealnog režnja odlična metoda i za augumentaciju prilikom primarne rekonstrukcije lateralnog ligamentarnog kompleksa gležnja, s obzirom na to da je dovoljno samo proksimalno produžiti rez i prikazati fibulu ${ }^{32}$.

$\mathrm{U}$ ovom radu prikazujem tehniku rekonstrukcije i ATFL-a i CFL-a s jednim periostealnim fibularnim režnjem koji se uzdužno rascijepi od proksimalno prema distalno i učvrsti distalno uz fibulu. Oba kraka periostealnog režnja koriste se za rekonstrukciju tako da se rotiraju preko položaja originalnih ATFL-a i CFL-a. Ova tehnika vjerno prati originalnu metodu. Mittlmeier i suradnici, međutim, navode da je u odraslih tkivo periosta fibule suviše oskudno da bi se istovremeno njime moglo rekonstruirati dva ligamenta ${ }^{46}$. Promatrajući navedenih 14 pacijenata, u 13 sam uspio rekonstruirati i ATFL i CFL bez poteškoća, s dostatnom duljinom i debljinom režnjeva tkiva periosta, koji 
je dovoljno čvrst i nije se kidao prilikom rekonstrukcije. Ako se intraoperacijski uoče ostaci originalnih ligamenata - oni se šavima učvrste za periostalni režanj. Postoje različite tehnike kojima se fibularni režanj fiksira za talus koštanim sidri$\mathrm{ma}^{38}$. Metalno sidro od titanske legure najčešće je korištena metoda. U ovom radu najveći broj pacijenata podvrgnut je ovom načinu fiksacije. lako vrlo čvrsta i sigurna, ova fiksacija je po svojim tehničkim karakteristikama fiksacija samo u jednoj točki, tj. ligament je prislonjen na kost neposredno iznad tunela sidra. Iz toga razloga s vremenom sam počeo koristiti Biotenodesis Screw (Arthrex) kojim se osigurava fiksacija dijela periostealnog režnja uz sidro, unutar kosti. lako nisam uočio nikakvih problema s implantatima, korištenjem sidra s fiksacijom ligamenta u kosti radi subjektivnog dojma bolje čvrstoće i kontakta režnja s koštanim tkivom, započeo sam s bržim rehabilitacijskim protokolom, te dozvoljavanjem pacijentima ranije i veće opterećivanje gležnja. Sarcon i sur. opisali su tehniku augumentacije rekonstrukcije lateralnog ligamentarnog kompleksa periostealnim režnjem s fibule, korištenjem koštanih sidara. U rehabilitaciji nakon zahvata autori dozvoljavaju neposredno opterećenje gležnja prema toleranciji, uz korištenje ortoze, a sa svrhom poboljšanja propriocepcije ${ }^{7}$. Mittlmeler i Rammelt opisali su tehniku kod koje se rekonstrukcija ATFL-a ili CFL-a može napraviti bez korištenja koštanih sidara. Pri tom se nakon podizanja režnja fibularnog periosta iz fibule uzima kortikalni presadak koji se utisne uz transponirani režanj na primateljskoj lokaciji, odnosno na mjestu na koje se režanj transponira (talus ili petna kost) ${ }^{46}$. U ovom radu $u$ analizu rezultata liječenja uključio sam i pacijenticu mlađe životne dobi kod koje je fiksacija napravljena kreiranjem koštanog tunela i šivanjem transosealnim koncima, no kod nje je istovremeno napravljena i subtalarna artordeza, a CFL nije rekonstruiran. U pogledu stabilnosti gležnja kod ove pacijentice nije bilo nikakvih osobitosti u poslijeoperacijskom procesu praćenja. Njezin rehabilitacijski tijek bio je nešto sporiji radi zahvata artrodeze. S obzirom na to da se od distalno prema proksimalno može uzeti dovoljna duljina periostealnog fibularnog režnja, nije bilo problema u fiksaciji tkiva u kosti talusa. $U$ djece i adolescenata periost je osobito zadebljan i čvrst i može se uzeti u duljem formatu, te provući kroz koštani tunel i duplirati te tako ojačati rekonstrukcija. Mathieu i suradnici pokazali su odlične rezultate u studiji provedenoj na četrnaestoro djece u pogledu porasta AOFAS-a; sa 61 prije operacije na 95 nakon operacije ${ }^{47}$. lako grupa od 14 pacijenata u mojem istraživanju nije bila homogena po pitanju načina fiksacije, ukupni rezultati AOFAS-a značajno su poboljšani kao i kod drugih studija. Prosječni AOFAS iznosio je 48,4 prije operacije, a nakon operacije i provedene re-

Odlika ove metode je da istovremeno daje mogućnost rekonstrukcije i prednjeg talofibularnog i kalkaneofibularnog ligamenta, što dodatno stabilizira i subtalarni zglob koji je nerijetko također suptilno nestabilan. Nedostatak metode je potreba izvođenja otvorenog zahvata. U budućnosti valja očekivati razvoj artroskopski asistirane stabilizacije gležnja periostealnim fibularnim režnjem.

habilitacije prosječno je iznosio 94,7. To je značajno povećanje na razini značajnosti od $5 \%$ i u cijelosti prati rezultate koji su objavljeni u literaturi, iako objavljene i uspoređivane tehnike nisu identične ${ }^{36,43,44}$. Hale i Hertel validirali su FADI (Foot and Ankle Disability Indeks) i preporučuju ga kao osobito dobar biljeg za evaluaciju kronične nestabilnosti gležnja, osobito kod mlađih osoba ${ }^{34}$. Prosječna dob pacijenata u mojem istraživanju bila je 37 godina, a testirani FADI porastao je značajno s 55,4 prije operacije na 92,4 nakon operacije. Dinamika porasta FADI biljega u potpunosti prati dinamiku porasta AOFAS-a. U ovom radu nije napravljena analiza rezultata u pogledu AOFAS i FADI biljega između pacijenata kod kojih su napravljeni različiti načini fiksacije. To je sigurno nedostatak ovog istraživanja i bilo bi interesantno vidjeti postoje li razlike $u$ ishodu liječenja i duljini oporavka s obzirom i na vrstu fiksacije periostealnog režnja. Prema mojim spoznajama takvo istraživanje nije objavljeno.

\section{ZAKLJUČAK}

Metoda augumentacije lateralnog ligamentarnog kompleksa gležnja fibularnim periostealnim režnjem pouzdana je metoda kod primarnih ali i 
sekundarnih zahvata stabilizacije gležnja kod kronične lateralne nestabilnosti gležnja. Periostealni režanj je čvrst, obilan presadak koji se izvrsno remodelira. Odabirom optimalne metode fiksacije postiže se izvrsna primarna čvrstoća rekonstruiranog kompleksa te pacijenti mogu započeti s brzim rehabilitacijskim postupkom, očekujući relativno brz povratak redovitim životnim i sportskim aktivnostima. Nedostatak metode korištenja periostealnog režnja jest u potrebi korištenja nešto većeg kožnog reza.

Izjava o sukobu interesa: Autor izjavljuje da ne postoji sukob interesa.

\section{LITERATURA}

1. Ajis A, Maffulli N. Conservative Management of Chronic Ankle Instability. Foot Ankle Clin N Am 2006;11:531-537.

2. Maffulli N, Ferran N. Management of Acute and Chronic Ankle Instability. JAAOS, 2008; 16:608-15.

3. Clanton TO, Campbell KJ, Wilson KJ, et al. Qualitative and quantitative anatomic investigation of the lateral ankle ligaments for surgical reconstruction procedures. J Bone Joint Surg Am 2014;96:e98.

4. Golano P, Vega J, de Leeuw PAJ, Malagelada F, Manzanares MC, Go"tzens V, van Dijk N. Anatomy of the ankle ligaments: a pictorial essay. Knee Surg Sports Traumatol Arthrosc 2010;18:557-69.

5. Pećina M. Nauka o spojevima kostiju. U: Jelena KrmpotićNemanić (ur.). Anatomija čovjeka. Zagreb: Jugoslavenska medicinska naklada, 1990; 50-53.

6. Ferran NA, Maffulli N: Epidemiology of sprains of the lateral ankle ligament complex. Foot Ankle Clin 2006; 11:659-662.

7. Sarcon AK, Heyrani N, Giza E, Kreulen C. Lateral Ankle Sprain and Chronic Ankle Instability. Foot \& Ankle Orthopaedics 2019;4:1-10.

8. Lee BH, Choi KH, Seo DY, Choi SM, Kim GL: Diagnostic validity of alternative manual stress radiographic technique detecting subtalar instability with concomitant ankle instability. Knee Surg Sports Traumatol Arthrosc 2016;24:1029-39.

9. Karlsson J, Bergsten T, Lansinger O, Peterson L. Reconstruction of the lateral ligaments of the ankle for chronic lateral instability. J Bone Joint Surg Am 1988;70:581-8.

10. Karlsson J, Bergsten T, Lansinger O, Peterson L. Surgical treatment of chronic lateral instability of the ankle joint. A new procedure. Am J Sports Med 1989;17:268-74.

11. Vuurberg G, Hoorntje A, Wink LM Brent, van der Doelen FW, van den Bekerom MP, Dekker R et al. Diagnosis, treatment and prevention of ankle sprains: update of an evidence-based clinical guideline. $\mathrm{Br} J$ Sports Med. 2018;52:956.

12. Hertel J. Functional anatomy, pathomechanics, and pathophysiology of lateral ankle instability. J Athl Train. 2002;37:364-75.

13. Freeman MA, Dean MR, Hanham IW. The etiology and prevention of functional instability of the foot. J Bone Joint Surg Br 1965;47:678-85.
14. Kobayashi T, Gamada K. Lateral Ankle Sprain and Chronic Ankle Instability: A Critical Review. Foot Ankle Spec, 2014;7:298.

15. Trevino, SG; Davis, P; Hecht, PJ: Management of acute and chronic lateral ligament injuries of the ankle. Orthop Clin N Am 25:1-16,1994.

16. Herb CC, Hertel J. Current concepts on the pathophysiology and management of recurrent ankle sprains and chronic ankle instability. Curr Phys Med Rehabil Rep 2014;2:25-34.

17. Renstrom PA, Lynch SA. Ankle ligament injuries. Revista Brasileira de Medicina do Esporte 1998;4:71-80.

18. Karlsson J, Lansinger O, Faxen E. Lateral instability of the ankle joint (2). Active training programs can prevent surgery. Lakartidningen 1991;88:1404-7.

19. Khoury V, Guillin RI, Dhanju J, Cardinal E. Ultrasound of Ankle and Foot: Overuse and Sports Injuries. Seminars in Musc Skel Radiol, 2007;11:149-61.

20. Kanamoto T, Shiozaki Y, Tanaka Y, Yonetani Y, Horibe S. The use of MRI in pre-operative evaluation of anterior talofibular ligament in chronic ankle instability. Bone Joint Res 2014;3:241-5.

21. Hattori S, Alvarez CAD, Canton S, Hogan MV, Onish K. UItrasound-Guided Ankle Lateral Ligament Stabilization. Current Reviews in Musculoskeletal Medicine, 2019; available from: https://doi.org/10.1007/s12178-01909592-0.

22. Chen Y. Diagnosis and Treatment of Chronic Ankle Instability. Intech Open 2019; available from: http://dx.doi. org/10.5772/intechopen.89485.

23. Guillo $S$, Bauerb $T$, Leec JW, Takao $M$, Konge SW, Stone JW, Mangoneg PG, Molloyh A, Pererai A, Pearce CJ, Michels F, Tourné $Y$, Ghorbanim A, Caldern J. Consensus in chronic ankle instability: Aetiology, assessment, surgical indications and place for arthroscopy. Orthop Traumatol Surg Res, 2013; available from: http://dx.doi. org/10.1016/j.otsr.2013.10.009.

24. Li H, Hua Y, Li H, Ma K, Li S, Chen S. Activity Level and Function 2 Years After Anterior Talofibular Ligament Repair A Comparison Between Arthroscopic Repair and Open Repair Procedures. The American Journal of Sports Medicine, 2017; available from: https://www.researchgate.net/publication/315928664.

25. Gould N, Seligson D, Gassman J. Early and late repair of lateral ligament of the ankle. Foot Ankle 1980;1:84-9.

26. Snook GA, Chrisman OD, Wilson TC. Long term results of the Chrisman-Snook operation for reconstruction of the lateral ligaments of the ankle. J Bone Joint Surg 1985: 67:1-7.

27. Watson-Jones R. Medullary nailing of fractures after fifty years; with a review of the difficulties and complications of the operation. J Bone Joint Surg Br 1950;32:694-729.

28. Bjorkenheim JM, Sandelin J, Santavirta S. Evans procedure in the treatment of chronic instability of the ankle. Injury 1988;19:70-72.

29. Becker HP, Rosenbaum D, Zeithammel G, Gerngro BH, Claes $\mathrm{L}$. Gait pattern analysis after ankle ligament reconstruction (modified Evans procedure). Foot Ankle Int 1994;15: 477-82.

30. Glas E, Paar O, Smasal V, Bernett P. [Periosteal flap reconstruction of the external ankle ligaments. Results of a follow-up study] Unfallchirurg. 1985;88:219-22. 
31. Rudert M, Wulker N, Wirth CJ. Reconstruction of the lateral ligaments of the ankle using a regional periosteal flap. J Bone Joint Surg Br 1997;79:446-51.

32. Ozaki K, Miyagi S, Tokunaga J. Anatomic Reconstruction of the Lateral Ligament of the Ankle Using a Periosteal Flap From the Fibula. Techniques in Foot and Ankle Surgery 2005;4:98-103.

33. Rosenbaum D, Engelhardt M, Becker HP, Claes L, Gerngrol H. Clinical and Functional Outcome After Anatomic and Nonanatomic Ankle Ligament Reconstruction: Evans Tenodesis Versus Periosteal Flap. Foot \& Ankle International 1999;20:636-9.

34. Kitaoka HB, Alexander IJ, Adelaar RS, Nunley JA, Myerson MS, Sanders M. Clinical rating systems for the anklehindfoot, midfoot, hallux and lesser toes. Foot Ankle Int 1994;15:349-53.

35. Hale SA, Hertel J. Reliability and Sensitivity of the Foot and Ankle Disability Index in Subjects With Chronic Ankle Instability. Journal of Athletic Training 2005;40:35-40.

36. Chew CP, Koo KOT, Lie DTT. Periosteal flap augmentation of the Modified Broström-Gould procedure for chronic lateral ankle instability. Journal of Orthopaedic Surgery 2018; 26:1-6.

37. Vuurberg G, Pereira H, Blankevoort L, van Dijk CN. Anatomic stabilization techniques provide superior results in terms of functional outcome in patients suffering from chronic ankle instability compared to non-anatomic techniques. Knee Surg Sports Traumatol Arthrosc, 2017; available from: https://doi.org/10.1007/s00167-017-4730-4.

38. Benazzo F, Zanon G, Marullo M, Rossi SMP. Lateral ankle instability in high-demand athletes: reconstruction with fibular periosteal flap. Int Orthopaedics (SICOT), 2013; 37:1839-44.

39. Matsui K, Takao M, Miyamoto W, Matsushita T. Early recovery after arthroscopic repair compared to open re- pair of the anterior talofibular ligament for lateral instability of the ankle. Arch Orthop Trauma Surg 2016;136:93-100.

40. Yeo ED, Lee KT, Sung IH, Lee SG, Lee YK: Comparison of all-inside arthroscopic and open techniques for the modified Broström procedure for ankle instability. Foot Ankle Int 2016;37:1037-45.

41. Järvelä K, Alavaikko $A$ : A novel reconstruction technique for chronic lateral ankle instability: Comparison to primary repair. Int Orthop 2002;26:314-17.

42. Chen CY, Huang PJ, Kao KF, Chen JC, Cheng YM, Chiang $\mathrm{HC}$ et al. Surgical reconstruction for chronic lateral instability of the ankle. Injury Int J Care Injured 2004;35: 80913.

43. Choi HJ, Kim DW, Park JS. Modified Broström Procedure Using Distal Fibular Periosteal Flap Augmentation vs Anatomic Reconstruction Using a Free Tendon Allograft in Patients Who Are Not Candidates for Standard Repair. Foot \& Ankle International 2017;38:1207-14.

44. Park CH, Park JJ. Effect of Modified Broström Procedure With Periosteal Flap Augmentation After Subfibular Ossicle Excision on Ankle Stability. Foot \& Ankle International 2019;40:656-60.

45. Bohnsack M, Surie B, Kirsch L, Wulker N. Biomechanical Properties of Commonly Used Autogenous Transplants in the Surgical Treatment of Chronic Lateral Ankle Instability. Foot \& Ankle International 2002;23:661-64.

46. Mittlmeier T, Rammelt S. Die Periostlappenplastik bei chronischer Instabilität des oberen Sprunggelenks. Oper Orthop Traumatol 2019;31:180-90.

47. Mathieu PA, Marcheix PS, Vacquerie V, Dijoux P, Mabit C, Fourcade L. Reconstruction of the Lateral Ligaments of the Ankle Using a Periosteal Flap in Children and Teenagers: A Midterm Follow-up Survey. J Pediatr Orthop 2015;35:511-15. 